\title{
Menakar Kesiapan SDM Syariah
}

\author{
Sudirman Tebba
}

The rapid development of Islamic Banking system in Indonesia is adorable. No more than 11 years since the regulation on banking in 1992, there are some big banks has open its Syariah bank windows. Accountless smaller Islamic banks are in operation. However, some serious problems must be inevitably solved soon, i.e., the problem on the provision of human resources. Faculty of Syariah, which is used to accustomed only to the classical figh need be reformed in the new curriculum and educational system. Similarly, graduant of faculties of Economics, need to hard work to understand the basis of Syariah Islamiyah in term of banking rather than conventional banking system. If the provision for such human resources fails, it will be embarrassing for Moslem society in the country because of inability to provide professional human resources.

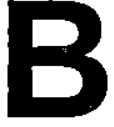
erkembangnya kegiatan-kegiatan ekonomi dan bisnis syariah belakangan ini, seperti di bidang perbankan, asuransi, koperasi, pasar modal dan multi level marketing merupakan peluang sekaligus tantangan baru bagi lembaga-lembaga pendidikan syariah untuk melahirkan sumber daya manusia (SDM) yang diperlukan untuk menopang kegiatan ekonomi dan bisnis syariah itu. Tantangan timbulnya peluang kerja yang lebih luas bagi para lulusan fakultas-fakultas syariah yang terdapat di perguruan tinggi Islam, baik negeri seperti Institut Agama Islam Negeri (IAIN) maupun swasta. Lulusan fakultas syariah selama ini umumnya untuk mengisi formasi di Kantor Urusan Agama (KUA) dan pengadilan agama (PA).

Peluang itu sekaligus merupakan tantangan baru berupa tuntutan bagi lembaga pendidikan syariah untuk menyesuaikan diri dengan perkembangan baru dalam kehidupan syariah. Perkembangan baru ini adalah meluasnya bidang penerapan syariah secara drastis dalam kehidupan ekonomi dan bisnis. Perluasan bidang penerapan syariah itu adalah diterima dan diterapkannya konsep syariah dalam kehidupan ekonomi dan bisnis, terutama di bidang:

1. Perbankan,

2. Asuransi,

3. Koperasi (Baitul Mal wa Tamwil-BMT),

4. Pasar modal (syariah index),

5. Pasar uang, dan

6. Multi level marketing.

Perluasan ini terjadi sejalan dengan perubahan fungsi syariah sekarang ini, karena fungsi syariah berkembang dan berubah dari waktu ke waktu. Misalnya menjelang kemerdekaan RI tahun 1945 timbul perdebatan tentang syariat Islam yang ditandai dengan kontroversi mengenai Piagam Jakarta. Piagam Jakarta adalah rancangan UUD 1945 yang dirumuskan pada 22 Juni 1945 di Jakarta. Dalam rancangan UUD ini, baik pada pembukaan maupun pada batang tubuhnya (pasal 29 ayat 1 ) ada katakata Ketuhanan dengan kewajiban menjalankan syariat Islam bagi pemeluk- 
pemeluknya. Kata-kata "dengan kewajiban menjalankan syariat Islam bagi pemelukpemeluknya" inilah yang merupakan esensi Piagam Jakarta. Tetapi kemudian tujuh kata ini dihapus sewaktu rancangan UUD disahkan pada 18 Agustus 1945.

Tujuh kata itu dihapus, karena sebagian golongan politik saat itu keberatan, karena khawatir nanti Indonesia menjadi negara Islam. Juga ada keberatan dari kalangan non Islam yang kabarnya daerah-daerah yang mayoritas penduduknya beragama Kristen mengancam akan memisahkan diri dari indonesia jika tujuh kata itu dipertahankan. Itu sebabnya golongan Islam berbesar hati menerima penghapusan ketujuh kata itu agar bangsa yang baru ini tidak pecah.

Perdebatan tentang syariat saat itu lebih banyak karena umat Islam ingin pelaksanaan syariat ini memiliki legitimasi konstitusional: Ini berarti bahwa syariat Islam saat itu berfungsi sebagai legitimasi. Tetapi setelah perjuangan untuk menjadikan syariat sebagai legitimasi konstitusional menemui kegagalan, maka kemudian umat Islam menjalankan syariah sebagai identitas keagamaan mereka, baik dalam ibadah, yakni shalat, puasa, zakat dan haji maupun dalam muamalat, khususnya perdata, lebih khusus lagi hukum kekeluargaan, seperti pernikahan, perceraian dan kewarisan.

Hal itu dibuktikan dengan pengajaran bidang-bidang syariah di lembaga-lembaga pendidikan Islam, seperti pesantren, madrasah dan perguruan tinggi. Bidangbidang syariah itu terdapat dalam fiqh, tafsir dan hadits. Malah di perguruan tinggi Islam negeri dan swasta terdapat fakultas syariah yang mengajarkan bidang-bidang syariah tadi. Hal ini terutama untuk melahirkan SDM yang mengisi KUA dan $P A$, dan selanjutnya pengadilan tinggi agama (PTA), yang menangani pernikahan, perceraian dan kewarisan.
Sejalan dengan menguatnya pelaksanaan syariah, terutama di masa Orde Baru, maka posisi PA yang semula lemah, kemudian menguat pula dengan keluarnya Undang-undang Peradilan Agama (UU No: 7 Tahun 1989). Dengan keluarnya undang-undang ini, maka putusan pengadilan agama tidak lagi harus dikukuhkan oleh pengadilan negeri, sebagaimana yang terjadi sebelumnya. Ini karena kedudukan pengadilan agama sudah sejajar dengan pengadilan negeri.

Keluarnya Undang-undang tentang Peradilan Agama kemudian diikuti dengan lahirnya Kompilasi Hukum Islam berdasarkan Instruksi Presiden RI No: 1 Tahun 1991. Kompilasi Hukum Islam meliputi: Perceraian, Kewarisan, Perwakafan.

Kompilasi Hukum Islam menjadi rujukan hakim dalam memutuskan perkara di pengadilan agama. Hal ini mempermudah pekerjaan hakim, karena Kompilasi Hukum Islam mengandung ketentuan hukum yang jelas dan pasti, yang disaring dari berbagai pendapat dan mazhab.

Sebelum lahirnya Kompilasi Hukum Islam pengadilan agama berpegang kepada 13 buku fiqh yang di dalamnya terdapat perbedaan pendapat di kalangan ulama. $\mathrm{Hal}$ ini sangat menyulitkan para hakim agama untuk menetapkan pendapat mana yang diambil untuk memutuskan suatu perkara.

Tetapi perkembangan hukum Islam atau syariat tidak sebatas dengan keluarnya Kompilasi Hukum Islam. Syariat terus berkembang sejalan dengan perkembangan umat Islam yang mempengaruhi fungsi syariah. Misalnya sekarang fungsi syariah berubah lagi dengan berkembangnya kegiatan ekonomi dan bisnis syariah di bidang perbankan, asuransi, koperasi, pasar modal, pasar uang dan multi level 
marketing. Fungsi syariah ini lebih sebagai sistem ekonomi dan bisnis yang berbeda dengan sistem ekonomi dan bisnis sekular. Ekonomi dan bisnis syariah menawarkan sistem bagi hasil (profit and loss sharing).

Bagi hasil berarti kalau ada keuntungan, maka keuntungan itu dibagi di antara pihakpihak yang bertransaksi sesuai dengan kesepakatan sebelumnya. Sebaliknya, kalau usaha itu merugi, maka kerugian pun ditanggung bersama di antara mereka. Dengan sistem ini tidak ada pihak yang menanggung kerugian sendiri, sementara pihak yang lain tetap memetik keuntungan.

Sistem bagi hasil itu berbeda dengan sistem bisnis sekular yang tidak mengenal bagi hasil, di mana ada pihak yang menderita kerugian, tetapi juga ada pihak yang memperoleh keuntungan. Misalnya pengusaha yang memperoleh pinjaman dari bank boleh jadi bisnisnya tidak selalu untung alias rugi, tetapi dia tetap harus memenuhi kewajibannya untuk mengembalikan pinjamannya itu ke bank berikut bunganya.

Sistem bagi hasil itu kelihatannya saat cukup diminati. Ini terlihat pada berkembangnya bank-bank dan asuransi syariah. Banyak bank konvensional mengembangkan bank syariah, misalnya Bank Syariah, Bank Syariah BNI, Bank Syariah BRI, lalu diikuti oleh bank-bank swasta yang juga mengembangkan sistem syariah.

Sistem syariah itu diminati tidak saja karena dianggap lebih adil, tetapi lebih mampu bertahan dalam menghadapi perkembangan ekonomi dan bisnis yang tidak menentu, karena diterpa oleh krisis yang berkepanjangan. Tampaknya faktor inilah yang menyebabkan berkembangnya bisnis syariah di masa krisis ekonomi ini.

Sementara bisnis sekular tampaknya kurang mampu menghadapi krisis ekonomi.
Buktinya banyak pengusaha bangkrut, sehingga tidak dapat mengembalikan kreditnya ke bank. Akibatnya kredit macet membengkak dan bank-bank pun sulit bertahan, dan akhirnya banyak bank yang harus ditutup.

Perkembangan bisnis syariah itu menuntut kuantitas dan kualitas sumber daya manusia (SDM) yang memadai. Menghadapi tuntutan ini kelihatannya fakultas-fakultas syariah yang ada sekarang di lembaga-lembaga perguruan tinggi Islam belum siap. Karena untuk mengisi formasi di bidang-bidang ekonomi dan bisnis itu fakultas-fakultas syariah yang ada sekarang harus lebih dahulu merombak kurikulumnya, karena tidak cukup lagi hanya mengajarkan hukum kekeluargaan, tetapi harus memasukkan pula mata kuliah manajemen.Hal itu sudah dilakukan di lingkungan Institut Agama Islam Negeri (IAIN) seperti yang terjadi pada IAIN (sekarang Universitas Islam Negeri - UIN) Jakarta. UIN telah mengadakan jurusan majemen di fakultas syariah, selain ada fakultas ekonomi.

Tetapi untuk mengajarkan ilmu manajemen, pengelola terbentur pada tenaga pengajar. Idealnya tenaga pengajarnya ialah orang yang menguasai syariah dan ilmu manajemen sekaligus. Tetapi tenaga pengajar yang ada sekarang umumnya hanya mengerti syariah atau hanya mengerti ilmu manajemen.

Pengajar yang tersedia adalah produk pendidikan masa lalu. Tenaga pengajar syariah adalah lulusan fakultas syariah yang hanya mengajarkan hukum kekeluargaan, sementara tenaga pengajar ilmu manajemen adalah lulusan lembaga pendidikan ekonomi dan manajemen yang tidak mengajarkan syariah.

Tenaga pengajar yang ideal itu mungkin nanti bisa diperoleh setelah mahasiswa 
jurusan manajemen fakultas syariah dan fakultas ekonomi di perguruan tinggi Islam itu lulus, lalu menjadi tenaga pengajar. Merekalah yang diharapkan dapat memadukan antara syariah dan ilmu manajemen sekaligus.

Para lulusan itu pula yang idealnya mengisi formasi di dalam kegiatan ekonomi dan bisnis syariah. Sekarang boleh dikatakan hampir semua SDM kegiatan ekonomi dan bisnis syariah bukan lulusan fakultas syariah. Akibatnya SDM syariah sekarang belum sepenuhnya ideal. Idealnya SDM syariah memiliki:pengetahuan manajemen,pengetahuan syariah,semangat dan perilaku islami.

SDM syariah saat ini umumnya hanya menguasai faktor yang pertama, yaitu pengetahuan manajemen. Sedang faktor kedua mungkin juga masih lemah, karena latar belakang pendidikan bukan syariah. Tetapi barangkali SDM hal ini masih bisa diatasi dengan mengikuti kursus dan pelatihan ekonomi dan bisnis syariah. Hanya saja faktor yang sulit dimiliki oleh SDM yang pendidikannya sekular, adalah kurangnya semangat dan perilaku islami. SDM yang ada belum tentu memiliki semangat dan perilaku islami, karena tujuan berdirinya ekonomi dan bisnis syariah berbeda dengan lembagalembaga Islam yang lain, seperti organisasi kemasya-rakatan Islam.

Ormas Islam didirikan dengan tujuan memperjuangkan Islam, tetapi ekonomi dan bisnis syariah murni bisnis yang tidak terkait dengan semangat Islam. Yakni bahwa ekonomi dan bisnis syariah menawarkan sistem alternatif terhadap ekonomi dan bisnis sekular.

Sistem ekonomi dan bisnis sekular yang berkembang saat ini dianggap tidak adil dan ekspioitatif, sehingga cenderung menimbulkan ketimpangan sosial. Sedang sistem syariah dengan sistem bagi hasil dianggap lebih adil, karena lebih menjamin pemerataan dan kemakmuran bersama.

Sebagai sistem ekonomi dan bisnis sistem syariah memang tidak mensyaratkan semangat dan perilaku islami bagi SDMnya, tetapi syariah adalah bagian dari Islam, sehingga selayaknya SDMnya memiliki semangat dan perilaku islami. Kalau bisnis syariah yang berkembang di negara-negara Barat yang mayoritas penduduknya nonmuslim dianggap sebagai sistem yang perlakuan SDMnya sama dengan bisnis nonsyariah, maka semangat dan perilaku islami SDMnya tidak penting.

Tetapi bisnis syariah di negeri ini berkembang setelah melalui perjuangan panjang umat Islam, sehingga selayaknya semangat dan perilaku islami dimiliki oleh SDMnya. Sebaiknya tidak terjadi bahwa setelah lama diperjuangkan oleh umat Islam lalu bisnis syariah berkembang, tetapi kemudian justru ditumpangi oleh orang-orang yang tidak memiliki semangat dan perilaku islami.

Bank syariah di negeri ini sudah diperjuangkan sejak lahirnya Majelis Ulama Indonesia (MUI) pada tahun 1975. Bank syariah yang kini sudah berkembang lebih maju di Malaysia semula ditawarkan kepada Indonesia, tetapi ditolak oleh rezim yang berkuasa saat itu (Orde Baru) dengan alasan tidak sesuai dengan undang-undang perbankan yang berlaku. Undang-undang perbankan menganut sistem bunga, sedang bank syariah menawarkan sistem bagi hasil.

Jadi, ada faktor sejarah dalam perkembangan sistem ekonomi dan bisnis syariah di negeri ini yang berbeda dengan perkembangan bisnis syariah di negaranegara Barat sekular saat ini. Faktor sejarah ini sebaiknya tidak diabaikan. Kalau diabaikan, maka motivasi berdirinya 
ekonomi dan bisnis syariah itu akan berubah pula, yang kemudian bisa mempengaruhi kenerjanya ke depan.

Pengaruh itu misalnya umat Islam kurang tertarik pada bisnis syariah, karena tidak ada bedanya dengan bisnis sekular. Bisnis syariah bisa dianggap sama dengan bisnis sekular, tetapi hanya dibungkus dengan simbol Islam. Karena itu, semangat dan perilaku islami seharusnya dimiliki oleh SDM syariah.

Tetapi, hal itu tampaknya masih lemah pada SDM syariah saat ini. Misalnya banyak karyawati, yang hanya mengenakan busana muslimah, jilbab dan rok panjang, selama berada di kantor syariah, sedang di luar kantor melepas jilbab dan rok panjang. Rok panjang kemudian diganti dengan rok pendek, yang kadang-kadang juga ketat, seperti yang biasa dijumpai pada karyawati bisnis sekular.

Bisnis syariah memang tidak mensyaratkan agama Islam bagi SDMnya, sehingga orang-orang nonmuslim boleh masuk menjadi pegawai usaha bisnis syariah. Tetapi tidak mungkin diharapkan memiliki semangat dan perilaku islami.

Dengan kurangnya dimiliki semangat dan perilaku islami oleh sebagian SDM syariah, maka hilanglah salah satu unsur penting dalam kehidupan bisnis, yaitu rasa memiliki (sense of belonging atau "melu handarbeni") terhadap usaha tempat mereka bekerja.

Dalam kehidupan bisnis saat ini SDM diharapkan mempunyai rasa memiliki supaya tidak sekedar bekerja mencari uang, tetapi juga semangat kerja keras untuk memajukan usahanya. Semangat kerja keras memajukan usaha hanya muncul kalau SDMnya ada rasa memiliki pada diri mereka.Dalam bisnis moderen sekarang, rasa memiliki saja terhadap usaha yang digeluti tidak cukup, tetapi harus mencintai pekerjaannya. Rasa cinta terhadap pekerjaan akan mendatangkan rasa puas dan bahagia dalam melakukan pekerjaannya. Sebaliknya, rasa kurang senang kepada pekerjaan akan mendatangkan kesengsaraan, seperti stres.Itu sebabnya disarankan dalam mencari pekerjaan hendaknya dipilih pekerjaan yang disenangi dan bukan yang sekedar mendatangkan uang yang banyak. Kalau orang menyenangi pekerjaannya, maka akan memiliki motivasi yang tinggi untuk bekerja keras guna memajukan usahanya

Ini berbeda dengan cara berpikir orang Indonesia. Pada umumnya, orang Indonesia mencari pekerjaan biasanya dilihat yang banyak uang atau tinggi gajinya. Akibatnya, mungkin dapat uang banyak, seperti yang diharapkan, tetapi belum tentu bahagia, karena pekerjaan itu kurang disenangi. Akhirnya uangnya banyak, tetapi tidak bahagia alias sengsara atau stres, kemudian sakit-sakitan.

Karena itu, rasa cinta dalam pekerjaan merupakan sesuatu yang mutlak. Dilihat dari segi tasawuf rasa cinta ini disebut mahabbah. Mahabbah memang prinsipnya berarti cinta pada Tuhan, tetapi konsep ini juga berarti cinta kepada ciptaan Tuhan, seperti alam dan isinya, termasuk pekerjaan, yang dimaksudkan dalam rangka mewujudkan cinta kepada Tuhan.

Dengan demikian, konsep mahabbah relevan dengan perkembangan bisnis moderen, lebih-lebih bisnis syariah, yang memang harus selalu mengacu kepada ajaran Islam, bukan hanya aturannya, tetapi juga semangatnya, sebagaimana yang ditanamkan dalam tasawuf.

Relevansi konsep tasawuf dalam kehidupan bisnis moderen semakin jelas dengan berkembangnya konsep 
kecerdasan emosional dan spiritual dalam bisnis dewasa ini. Artinya dalam kehidupan bisnis moderen tidak hanya diperlukan IQ yang tinggi, dalam hal ini pengetahuan manajemen, tetapi juga harus memiliki kecerdasan emosional dan spiritual.

Kecerdasan emosional adalah kemampuan mengenali perasaan kita sendiri dan orang lain, kemampuan memotivasi diri sendiri, dan kemampuan mengelola emosi dengan baik pada diri sendiri dan dalam hubungan dengan orang lain.Dengan demikian, kecerdasan emosional mencakup kesadaran diri, pengaturan diri, motivasi, empati dan keterampilan sosial. Kesadaran diri berarti mengetahui apa yang dirasakan pada suatu saat dan menggu-nakannya untuk memandu pengambilan keputusan diri sendiri, memiliki tolok ukur yang realistis atas kemampuan diri dan kepercayaan diri yang kuat.Sedang kecerdasan spiritual ialah pikiran yang mendapat inspirasi, dorongan dan efektivitas yang terinspirasi, penghayatan ketuhanan yang di dalamnya kita semua menjadi bagian.

Prinsip-prinsip kecerdasan emosional dan spiritual itu juga terdapat dalam tasawuf. Selain ada konsep mahabbah, ada konsep sabar, ikhlas, muhasabah (introspeksi diri), raja' (optimisme), syaja'ah (berani karena benar), itsar (mendahulukan orang lain), shidiq (benar dan jujur), istiqamah (konsisten), dan sikap-sikap sufistik lainnya yang sangat positif dalam menjalani hidup ini.

Sikap sufistik itu juga bermanfaat dalam kehidupan bisnis, lebih-lebih bisnis syariah.Hal ini karena sikap sufistik ini dapat mendorong SDM bisnis syariah untuk menanamkan rasa memiliki, malah rasa mencintai pada diri mereka terhadap bisnis yang dijalankannya.Kalau rasa memiliki apalagi rasa mencintai ada pada diri masing-masing SDM bisnis syariah, maka hal ini dapat menjadi salah satu faktor pendorong keberhasilan bisnis ini. Sebaliknya, rasa kurang memiliki atau rasa tidak cinta SDM bisnis syariah terhadap bisnis ini dikhawatirkan dapat memperlemah kinerja bisnis syariah dalam perkembangannya ke depan.

Sayangnya SDM bisnis syariah saat ini kelihatannya memang kurang mempunyai rasa memiliki terhadap bisnis. Ini terlihat pada kurangnya penghayatan mereka terhadap nilai-nilai Islam, khususnya yang mudah kelihatan adalah karyawati.Kalau rasa memiliki saja masih kurang, apalagi rasa cinta kepada bisnis ini. Kurangnya rasa memiliki itu dikhawatirkan mempengaruhi kinerja bisnis syariah, yang saat masih amat lemah. Buktinya di bidang perbankan misalnya, bidang bisnis syariah yang paling menonjol di antara bidang-bisnis bisnis syariah lainnya, omsetnya baru 0,5 persen dari total omset industri perbankan nasional setelah berkembang selama lebih 10 tahun. Bank syariah ditandai dengan lahirnya Bank Muamalat Indonesia (BMI) yang mulai beroperasi tahun 1992.

\section{Penutup}

Perkembangan itu dianggap terlalu lambat dalam kehidupan bisnis. Kelambatan dan kelemahan ini disebabkan oleh banyak faktor, di antaranya diduga soal SDM yang belum siap.Karena itu, agaknya diperlukan pembenahan SDM bisnis syariah, bukan saja kemampuain teknisnya, tetapi yang tak kalah pentingnya adalah perlunya dikembangkan semangat dan perilaku islami, rasa memiliki dan rasa cinta mereka kepada bisnis syariah. Untuk ini mungkin diperlukan seleksi ulang terhadap SDM bisnis syariah saat ini.

Apalagi kalau diingat bahwa banyak SDM bisnis syariah, terutama bank syariah, 
saat ini merupakan limpahan dari karyawan bank-bank swasta yang dilikuidasi. Bankbank yang dilikuidasi itu adalah bank-bank sekular yang jauh dari ruh Islam. Sekarang SDM tersebut berada di bank syariah, yang sama sekali berbeda dengan bank sebelumnya, tidak hanya menuntut pengetahuan manajemen, tetapi juga semangat dan perilaku islami. Oleh karena itu karena itu, diperlukan pembenahan SDM syariah. Kalau tidak, maka dikhawatirkan dapat berdampak buruk terhadap perkembangan bisnis syariah, yaitu kinerjanya masih akan tetap lambat dan lemah, sehingga tidak diperhitungkan dalam kehidupan bisnis di tanah air. Bahaya yang mungkin muncul dari kelambatan dan kelemahan bisnis syariah itu adalah kemungkinan timbulnya kesan bahwa seolah-olah sistem bisnis syariah tidak bisa menjadi alternatif dan solusi terhadap krisis ekonomi dan bisnis masyarakat modern.

Jika asumsi ini terbukti benar, maka tidak mustahil bisnis syariah akan mengalami bumerang yang kemudian memukul balik bisnis ini ke titik nol. Bila ini terjadi, maka ini merupakan kemunduran dan kekalahan dalam perjuangan Islam di Indonesia.Padahal sebenarnya yang salah bukan sistemnya, tetapi antara lain SDMnya yang belum siap. Inilah tantangan besar yang dihadapi bisnis syariah ke depan. Semoga selalu diberi hidayah dan kekuatan oleh Allah untuk mengatasi masalah ini.

\section{Daftar Pustaka}

Abdur Rahman I, 1990. Doi, Shari'ah: The Islamic Law ,Kuala Lumpur: AS Noordeen.

Achmad Roestandi dan Muchjidin Effendie, 1991, Komentar atas Undang-undang No: 7 Tahun 1989 tentang Peradilan Agama
Dilengkapi Kompilasi Hukum Islam (Bandung: Nusantara Press).

Cece Ramli Bihar Anwar, ed.,2002, Menyinari Relung-relung Ruhani: Mengembangkan EQ dan SQ Cara Sufi (Jakarta: IIMAN dan Hikmah).

Daniel S. Lev, 1986, Peradilan Agama islam di Indonesia: Suatu Studi tentang Landasan Politik Lembaga-lembaga Hukum, terjemahan Ahmad Noeh (Jakarta: Intermasa).

Endang Saifuddin Anshari, 1997, Piagam Jakarta 22 Juni 1945: Sebuah Konsensus Nasional tentang Dasar Negara Republik Indonesia (1945 - 1949), (Jakarta: Gema Insani Press).

Fuad Jabali dan Jamhari, ed., 2002, IAIN dan Modernisasi Islam di Indonesia (Ciputat: Logos).

Kwik Kian Gie, 1998, Praktek Bisnis dan Orientasi Ekonomi Indonesia (Jakarta: Gramedia dan Sekolah Tinggi llmu Ekonomi (BII).

Marsha Sinetar, 1995, To Build the Life You Want, Create the Work You Love: The Spiritual Dimension of Entrepreneuring, (New York: St. Martin's Press).

Sutan Remy Sjahdeni,1999, Perbankan /slam dan Kedudukannya dalam Tata Hukum Perbankan Indonesia (Jakarta: Pustaka Utama Grafiti).

Zainul Arifin,2000, Memahami Bank Syariah: Lingkup, Peluang, Tantangan dan Prospek (Jakarta: AlvaBet). 